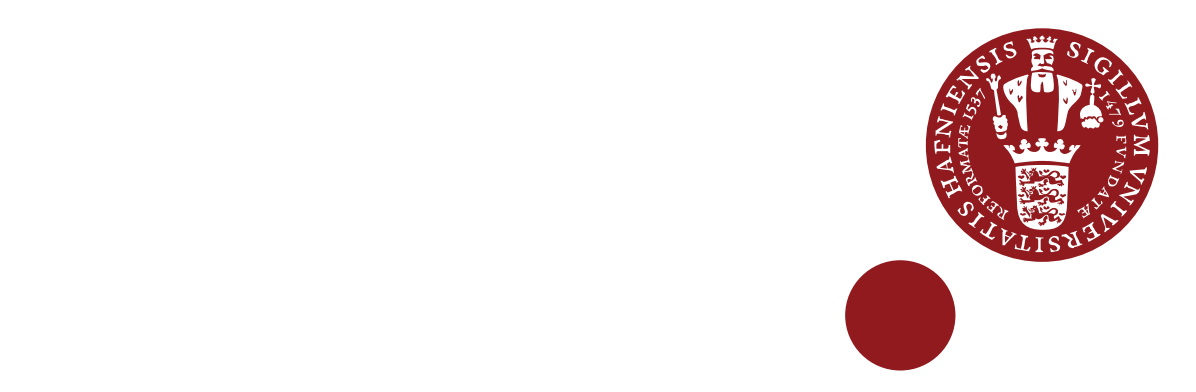

\title{
iCourts
}

iCourts Working Paper Series, No. 198, 2020

IMAGINE Paper No. 5

\section{The Imaginary and the Unconscious: Situating Constitutional Pluralism}

\author{
The First IMAGINE Workshop
}

\author{
Amnon Lev \\ iCourts - The Danish National Research Foundation's \\ Centre of Excellence for International Courts
}

July 2020 


\begin{abstract}
:
The article interrogates Neil Walker's theory of constitutional pluralism in order to bring out the importance of ideas for how we theorise the EU legal order. To that end, the article introduces two conceptual tools or prisms, the imaginary and the unconscious. The first part of the article situates Walker's work in relation to the body of state-centric constitutional theory. It shows the steps Walker takes to attach his theory to past constitutionalisms, and it argues that the focus on theory leads him to blank out the question of state practice. The second part of the article considers the ideas and conceptual moves that pass from the body of constitutional theory to Walker's theory. What the analysis brings into view is a stock of basic ideas, an imaginary around which Walker's theory revolves. In the third part the article shows that the continuity between past and present formats of constitutional theory rests upon a determinate, and historically specific, intuition of political life. It argues that the changes Walker shall make to his theory can be explained in terms of the passing of a specific historical conjuncture, in which law could transcribe politics and keep economic rationality at bay.
\end{abstract}

KEYWORDS: constitutional pluralism, social imaginary, the political unconscious, Neil Walker

Amnon Lev is Associate Professor in the Faculty of Law, University of Copenhagen

E-mail: Amnon.Lev@jur.ku.dk

IMAGINE has received funding from the European Research Council (ERC) under the European Union's Horizon 2020 research and innovation programme (grant agreement No 803163). 
The iCourts Working Paper Series is funded by the Danish National Research Foundation Grant no. DNRF105.

iCourts - Centre of Excellence for International Courts - focuses on the ever-growing role of international courts, their place in a globalizing legal order, and their impact on politics and society at large. To understand these crucial and contemporary interplays of law, politics, and society, iCourts hosts a set of deeply integrated interdisciplinary research projects on the causes and consequences of the proliferation of international courts.

iCourts opened in March 2012. The centre is funded by a large grant from the Danish National Research Foundation (for the period 2012-18). 


\section{THE IMAGINARY AND THE UNCONSCIOUS: SITUATING CONSTITUTIONAL PLURALISM}

Amnon Lev*

Considering that commitment to the project of European integration is, for most, a commitment to the idea of what Europe is, or could become, it is remarkable how few attempts have been made to interrogate the constitutionalism of the European Union in terms of its guiding ideas. ${ }^{1}$ No doubt, the reasons for this are, in large part, methodological. Ideas are so deeply embedded in how we perceive and make sense of the world that they resist full scrutiny. Just as we cannot turn our eyes on themselves, we cannot rise above our ideas. They frame our mental vision; their limits are our limits. This blinkering effect was already a concern to the sensualist school of philosophy around Destutt de Tracy that coined the term ideology. ${ }^{2}$ It underlies the quest of Karl Marx, and the different strands of theory he inspired, to unmask the ideological distortion of social reality. ${ }^{3}$ These formidable questions hover in the background as we pursue the more modest aim of trying to understand how ideas inform the constitutionalism of the European Union. The point of the exercise is twofold: first, we want to make the case that ideas matter for how we theorise the legal order of the European Union. Second, we shall want to say something about how, by what methods, we can study the role of ideas in constitutional theory. Of the two enquiries, the latter is the most urgent. At present, what holds back the efforts to study the imaginary of EU constitutionalism is a naïve belief that we can access ideas through the selfreporting of those who employ them. The point we shall make is that more rigorous methods of analysis are

\footnotetext{
* I would like to thank Jan Komárek and Michael A. Wilkinson for their insightful comments to this article. The paper was written as part of a workshop organized in the framework of the Project IMAGINE, which has received funding from the European Research Council (ERC) under the European Union's Horizon 2020 research and innovation programme (grant agreement No 803163).

${ }^{1}$ For two exceptions, see András Jakab, European Constitutional Language (Cambridge: Cambridge University Press, 2016); Andrew Williams, The Ethos of Europe: Values, Law and Justice in the EU (Cambridge: Cambridge University Press, 2010).

${ }^{2}$ See Antoine-Louis-Claude Destutt de Tracy, Élémens d'idéologie, I: Idéologie proprement dite (Paris: Librairie Philosophique J.VRIN, 1970 (1817), xvi, p. 349). On the (dis)continuity between French sensualist philosophy and Marx’s materialism, see Patrick Quantin, Les origines de l'idéologie (Paris: Economica, 1987), pp. 174-1183.

${ }^{3}$ Marx was acutely aware that ideology was a function of language. In his work on the German ideology fell back on the philosophically untenable idea of a wholly transparent language that would not be susceptible to ideological distortion; materialism represents, he tells us, the "language of life"; man's "mental discourse" is a "direct efflux" of his material conditions (Karl Marx, The German Ideology (London: Lawrence \& Wishart, 1976), p. 36). On this point, see Étienne Balibar, La crainte des masses. Politique et philosophie avant et aprés Marx (Paris: Galilée, 1997), pp. 174-189.
} 
needed, methods that require us to situate constitutional theory in history, or rather, in two histories: the history of that discourse on the one hand, and the history it purports to govern on the other.

We shall approach EU constitutionalism through a reading of one of its most influential positions, Neil Walker's theory of constitutional pluralism. Much has been written on the subject of constitutional pluralism; most of it concerned with assessing whether it picks out something essential about how the EU member states order their legal relations, and how they distribute rights and competencies within the union jurisdiction. We shall take another approach: rather than assess the accuracy of constitutional pluralism as a description of institutional practices or self-understandings "out there," or consider its merits as a format for how to integrate different constitutional orders, we shall use constitutional pluralism as an object lesson in how to analyse the place and function of ideas in constitutional theory. We shall argue that constitutional pluralism is best understood as a constellation of ideas that are ordered around what we might call a historically specific intuition of social life that constitutional discourse cannot articulate, or even acknowledge, but without which it cannot become operative. ${ }^{4}$

Today we are more attuned to this way of approaching constitutional theory. Martin Loughlin's work on political jurisprudence has familiarised us with the idea that intuitions of the social are a component part of the theory of political right. Political jurisprudence involves appraising how well the body of rules that govern social life in a given polity align with the material, or substantive, power formations in society. ${ }^{5}$ This intuition holds the key to calibrating governmental intervention so as to maintain a balance between competing conceptions of social justice. To Loughlin, constitutional discourse, in all its different forms and iterations, is concerned with managing the same fissure between the formal/legal and the substantive/social, and the account he gives of those efforts constitutes a unitary, albeit ambivalent, history of political modernity that begins in the mid-sixteenth century and continues right up to the work of Michael Oakeshott.

We shall, on the contrary, want to stress how constitutional theory changes as we move between epistemic regimes that frame distinct intuitions of the social. So a story of rupture and discontinuity. The account we shall give of the trajectory of theory relies on two key terms: the imaginary and the unconscious. According to a definition that is fast becoming standard, the social imaginary is concerned with the common meanings that make common practices possible. ${ }^{6}$ We shall use the term in the more restricted sense given to it

\footnotetext{
${ }^{4}$ The notion of constellation used here builds on Walter Benjamin's seminal reflections on methodology in his work on the origin of German tragic drama (see Walter Benjamin, Ursprung des deutschen Trauerspiels in Rolf Tiedemann and Hermann Schweppenhäuser (eds.), Walter Benjamin. Gesammelte Schriften (Frankfurt: Suhrkamp Verlag, 1980), I, 1, pp. 210-215).

${ }^{5}$ Martin Loughlin, Foundations of Public Law (Oxford: Oxford University Press, 2010), pp. 161-164. For another account of European integration as a story of secularisation, see Nathan Gibbs, "Post-Sovereignty and the European Legal Space," (2017) 80(5) Modern Law Review 833. Gibb's account demonstrates the loss of analytical purchase that comes with such a comprehensive historical sweep.

${ }^{6}$ Charles Taylor, Modern Social Imaginaries (Durham: Duke University Press, 2004), p. 23.
} 
by Cornelius Castoriadis for whom the social imaginary deals not with practice but with a collectivity's prior institution of itself as a reflexive agent. ${ }^{7}$ The unconscious, or political unconscious, a term we borrow from the work of cultural theorist Fredric Jameson, designates the ways social contradictions that constitute specific historical conjunctures condition the work of a text. The argument we shall make is that we require both approaches to understand the work that ideas are doing in constitutional pluralism.

The demonstration is quite pedestrian in that we consider each term in turn, to see how it operates in Walker's theory. The first part of the article situates that theory in relation to state-bound constitutional theory. It shows the steps Walker takes to attach his theory to the body of state-centric constitutional theory. As we shall see, Walker's focus on theory leads him to neglect the question of practice, which comes back to haunt his work. The second part of the article considers the ideas and conceptual moves that pass from the body of state-centric constitutional theory to Walker's theory. What the analysis brings into view is an imaginary around which constitutional pluralism revolves. At the same time, the analysis demonstrates that we cannot, from within theory, account for the continuity between past and present formats of theory. To do that, we must take into consideration the way theory adapts itself to the historical situation it purports to govern. This is the subject of the third part, which shows that Walker's theory rests on a determinate, and historically specific, intuition of political life. Seeing how theory link up allows us to understand how the idea of pluralism could make its way as a template for the constitutional discourse on the European Union. It also allows us to understand the meaning of the changes he shall make to his theory, changes that reflect the passing of a historical conjuncture, in which law could transcribe politics, and keep economic rationality at bay.

\section{Constitutional Pluralism: An Exercise in Theory}

While there are earlier avatars of the idea of constitutional pluralism, its lineage as a constitutional theory goes back to a 1995 article by Neil MacCormick. In a comment on the Maastricht judgement of the German Constitutional Court he advanced the claim that, in the EU, final interpretive power remains with the various legal systems involved; the "most appropriate" analysis of the relations between legal systems is "pluralistic rather than monistic." Neil Walker, MacCormick's successor as Professor of Public Law at the University of Edinburgh, elaborated this intuition into a philosophically articulate constitutional theory. Of Walker's numerous interventions on constitutional pluralism, we shall focus on two, decisive, interventions, written fourteen years apart, in 2002 and 2016. The point of the analysis of the 2002 intervention is, first, to identify

\footnotetext{
${ }^{7}$ Cornelius Castoriadis, The Imaginary Institution of Society (Cambridge: Polity Press, 1997), p. 364. Our concern here is with the central imaginary, not with the secondary imaginaries that extend from it (p. 129).

${ }^{8}$ Neil MacCormick, "The Maastricht-Urteil: Sovereignty Now," European Law Journal, 1/3, 1995, p. 264. MacCormick present a fuller account of the theory in Questioning Sovereignty: Law, State, and Nation in the European Commonwealth (Oxford: Oxford University Press, 1999).
} 
the basic ambition of Walker's theory, viz. to attach his work on European legal order to earlier, state-bound iterations of constitutional theory. We shall then consider how this continuity plays out in terms of basic ideas or concepts of constitutional theory that serve as conduits between the different conjunctures to which constitutional theory is tied. This is the imaginary that features in the title of this article. As we shall see, the analysis of the imaginary cannot fully account for how constitutional pluralism operates as a theory. Thus, we are led to consider the unconscious, and the question of how the way a theory is situated in history works back on the theory.

In the 2002 article, Walker is concerned to establish the theoretical pedigree of constitutional pluralism. The challenge he faces is to show that constitutional pluralism can deliver on the expectations that have grown up around the modern project of constitutional theory. To do so, constitutional pluralism would have to address a shift of authority away from the state, which has left those committed to the project of constitutionalism "fearing that they can no longer collectively do anything with it." ${ }^{9}$ Walker wants to show that a constitutionalism fit for a world no longer dominated by the state would be continuous with the past constitutionalisms that have shaped our notions of what a right-ordering of political life entails: "We must be able to understand constitutionalism not only as a history of the response to and of the (re)shaping of events and structures, but also a history of a particular discourse, in which the core ideas of that discourse, however radically transformed, are meaningfully connected between different times and places."10

Walker demonstrates the continuity of constitutionalist discourse by tying his pluralist theory to the state. To be sure, Walker's resetting of constitutionalism looks and feels very much like a disruption in that he dissociates constitutionalism from its traditional domain without tying it to another. But in this new open-ended setting, the state continues to be the primary unit of analysis, only now it is flanked, and to some extent overlaid, by constitutional phenomena that are neither bound to a polity nor fated to crystallise into one. Walker does not define these phenomena that are not delimited by territory but by sectoral and functional considerations. Instead he proposes a series of criteria by reference to which it can be determined whether these new constitutional phenomena can be treated in constitutional discourse. The most important of these criteria is polyvalence. Constitutional discourse is meaningful, and can be meaningfully engaged in, where the issue that falls to be considered is polyvalent, and "the agency charged with its treatment [is] empowered to have full regard to this polyvalence." 11

Polyvalence belongs to a semantic register we do not normally associate with law, but the meaning is clear: polyvalence tracks the indeterminacy of an object or a state of affairs the qualification of which under law calls for the exercise of judgement. Polyvalence warrants the need for, and the possibility of, resolving

\footnotetext{
${ }^{9}$ Neil Walker, "The Idea of Constitutional Pluralism," The Modern Law Review, 65/3, 2002, p. 333.

${ }^{10}$ Neil Walker, "The Idea of Constitutional Pluralism," p. 334.

${ }^{11}$ Neil Walker, "The Idea of Constitutional Pluralism," p. 348.
} 
conflicts through a process that looks like adjudication. Given that sovereignty and public law have been tied always to the saying of the law, it stands to reason that pluralism, on this reading, is well-placed to carry on the traditional functions of constitutionalism, even outside its traditional domain.

At this high level of abstraction, we cannot assess whether, and to what extent, Walker's pluralist theory does in fact meet the normative expectations that have built up in relation to constitutionalism across the range of new phenomena it now needs to cover. For our purposes, what matters is that, at this point, he is mainly concerned to show that constitutional pluralism succeeds as theory. Walker is sanguine about the prospects for success. Constitutionalism is capacious enough to accommodate the shifting of authority away from the state, and so to preserve the unitary world of meanings of which we once believed the state to be the sole source and foundation. The "new questions" of constitutionalism, he tells us, "are best considered as extending rather than eclipsing the older [state-centric] discourse."12

Such is the concern with establishing the continuity of theory that a number of important questions relating to constitutional pluralism are not raised. The perhaps most important question concerns the status of the practice that underlies theory. As he first seeks to capture constitutional pluralism in the 2002 article, Walker assumes that the practice which theory is supposed to reflect is already given. This shall change as he revisits his theory fourteen years hence. We shall have more to say about that later. In 2002, the problem is, quite simply, that theory has not caught up to what is already a reality in practice. In the architecture that has replaced the Westphalian world of monadic states, state power is no longer tied to territory. It follows other differential matrices that situate it within, rather than against, constitutionalism. This intuition is the key to Walker's hypothesis, developed in other work of the same period, that sovereignty has entered a late phase: "[Within] the more fragmented, fluid and contested configuration of authority of a multi-dimensional order, sovereignty too, like the other indices of constitutionalism, becomes more amenable to understanding as a graduated and tenuous property of normative order."13

For most of the road it has to travel, the development of the idea of late sovereignty runs parallel to the demonstration that constitutionalism's remit extends beyond the territory of the state to configurations of authority that are functional or sectoral. As we have seen, Walker relies on the judicially flavoured notion of polyvalence to show that constitutional discourse can engage with these new phenomena in a meaningful way. The demonstration that sovereignty too can be graduated proceeds on the assumption that irrespective of how far back we retrench the domain over which it is sovereign, sovereignty will always and everywhere delimit the same terms. We should "view the sovereignty claim as being necessarily situated at the boundary between

\footnotetext{
${ }^{12}$ Neil Walker, "The Idea of Constitutional Pluralism,” p. 353.

${ }^{13}$ Neil Walker, "The Idea of Constitutional Pluralism," pp. 347.
} 
politics and law." ${ }^{14}$ Retrenching sovereignty might generate new politics, but the configuration of authority will not change. Late sovereignty trades in the same currency as the Westphalian original, which is why Walker can assure us that the trajectory of sovereignty will be one of "continuous evolution rather than [...] demise." 15

This is the belief that underpins the pluralist reconfiguration of constitutionalism, a belief that if reconfiguring constitutionalism is sure to give rise to a novel political form, it will not disrupt history. This belief ties constitutional pluralism to a body of theory it identifies as its past, and to a present/future that finds expression in theory and in practice. We shall consider each of these links in turn.

\section{The Imaginary}

Neil Walker alludes to the continuity between constitutional pluralism and earlier formats of public law theory in describing his own demarche as that of letting "traditional 'international' relations between states develop in new 'constitutional' ways." 16 The relations he posits as a standard are those that obtained within the European state system. ${ }^{17}$ In what follows we shall consider how the European state system was theorised. The point of the exercise is to determine what constitutional pluralism takes from the tradition of European public law theory, and where it departs from the original. As we shall see, this shall take us to a limit of theory, and from the imaginary to the unconscious.

From the sixteenth century, the theorising of order in Europe proceeded on the assumption of a selfcorrecting mechanism that maintained equilibrium between states. ${ }^{18}$ It was believed that were a state to become too powerful, the imbalance would be met with concerted action by other states. Without fail, they would act to stop local supremacy from developing into global hegemony. States, it was believed, had no choice but to

\footnotetext{
${ }^{14}$ Neil Walker, "Late Sovereignty in the European Union" in Neil Walker, (ed.), Sovereignty in Transition (Oxford: Hart Publishing, 2003), p. 20.

${ }^{15}$ Neil Walker, "Late Sovereignty in the European Union," p. 28. The Treaty of Westphalia was in fact predicated on an imperial system of governance, and so did not posit the state as a monad, a conception that would only develop in nineteenth century state theory (see Randall Lesaffer, "Peace Treaties in the Formation of International Law" in Bardo Fassbender and Anne Peters (eds.), Oxford Handbook of the History of International Law (Oxford: Oxford University Press, 2012), p. 86; Andreas Osiander, "Sovereignty, International Relations, and the Westphalian Myth," International Organization, 55 (2011), pp. 264-266, 269). This point is not of historical interest only. It suggests that Walker is mistaken about the context, and possibly about the drivers, of the transformation of sovereignty that opened up a venue for integrating governmental authority in Europe. We shall have more to say about that.

${ }^{16}$ Neil Walker, "The Idea of Constitutional Pluralism," pp. 355.

${ }^{17}$ In a perspective different from ours, the structural similiary has been noted by Julio Baquero Cruz, "The Legacy of the Maastricht-Urteil and the Pluralist Movement," European Law Journal, 14/4, 2008, p. 418; Paul Kirchhof, "The Legal Structure of the European Union as a Union of States" in Armin von Bogdandy and Jürgen Bast (eds.), Principles of European Constitutional Law (Oxford: Hart Publishing, 2006), p. 794.

18 Heinz Duchhardt, Gleichgewicht der Kräfte, Convenance, Europäisches Konzert: Friedenskongresse und Friedensschlüsse vom Zeitalter Ludwigs XIV. bis zum Wiener Kongress (Darmstadt: Wissenschaftliche Buchgesellschaft, 1976), p. 68.
} 
oppose action that threatened the existence of another state as their own survival was predicated on the continued existence of the system. Ultimately, belief that the system would automatically self-correct rested on a politico-metaphysical article of faith which taught that, this side of eternity, authority would not again be gathered into a single point as it had been in the Roman Empire. This faith sustained early modern publicists as they fought to uphold the power of their temporal lords against the claims of the Holy Roman Emperor. It explains the confidence with which Montesquieu, in his reflections on universal monarchy, declares that, even if initially successful, attempts to unite Europe by conquest would inevitably lead to its fragmentation into an "infinity of Sovereignties" as it had done in the time of Charlemagne. ${ }^{19}$

The equilibrium system relied on the constant use of force to maintain its stability. Conflict was endemic, but it was not of a nature to overturn the system. Rousseau made the point that, while it was in a state of constant agitation, Europe was fundamentally immobile. It had a "degree of solidity that will keep it in a state of perpetual unrest without ever overturning it completely ... henceforth great revolutions are impossible." ${ }^{20}$ It is not hard to see why the equilibrium system might inspire diffidence. Even its champions were concerned that the remedy might prove to be just as bad as the disease. Allowing countermeasures to be taken against "dangerous excesses of power" did not offer assurance that such countermeasures would not in turn be used to promote self-serving ends and so give rise to new conflicts. ${ }^{21}$ In fact, it was all but certain that they would, seeing that the system had "no absolute principle, no fixed goal, [its] essence [being] that of neverending oscillation, mutual self-suspension, and boundless disloyalty in the shifting of alliances and breaking of treaties ..."22

This anarchic state, a function of the primacy of sovereignty, represents the formal reality of the state system. It is, however, only half the story of how the system operated. The theorising of the equilibrium system relied on ideas of cultural unity between the states of Europe to constrain and align action that was unbounded in law. The workings of this stock of ideas, this imaginary, come into view in relation to what lay outside Europe's borders. If sovereignty meant that the international state of nature was always a virtual state of war, as Hobbes argued, the fact of belonging to the same cultural air meant that anarchy could not be the final word within, between Europe's states. In positing a civilisational divide between Europe and the rest of the world, theorists gave themselves the opportunity of anchoring a law that could not be imposed from without (as this

${ }^{19}$ Charles-Louis de Secondat Montesquieu, Réflexions sur la monarchie universelle en Europe (Genève: Libraire Droz, 2000), p. 84. On this point, see Maurizio Bazzoli, "L'idea d'ordine internazionale nell'Europa di Montesquieu” in Alberto Postigliola and Maria Grazia Bottaro Palumbo (eds.), L'Europe de Montesquieu (Napoli: Liguori Editore, 1995), pp. 6263.

${ }^{20}$ Jean-Jacques Rousseau, Paix perpétuelle in Euvres complètes (Paris: Éditions Gallimard, 1964), III, p. 570.

${ }^{21}$ See August Wilhelm Heffter, Das Europäische Völkerrecht der Gegenwart (Berlin: Verlag von H.W. Müller, 1882), § 6, p. 13; Theodore A.H. Schmalz, Das europäische Völkerrecht (Berlin: Duncker \& Humblot, 1817), V, iv, p. 207.

${ }^{22}$ Heinrich Bernhard Oppenheim, System des Völkerrechts (Stuttgart: Kröner Verlag, 1866), I, iii, § 4, p. 32 . One finds the same analysis in Gabriel Bonnot de Mably (London, 1789), Principes des Négociations, x, p. 91; ix, pp. 79-81). 
would contradict the principle of sovereignty) in the moral personality of the state. Civilisation would make states do of their own accord what they could not be compelled to do. The implication of civilisation and rulefollowing is affirmed in terms that admit of no uncertainty by Carl Bergbohm: "Guided by deeper insight than the politically undeveloped peoples that habitually follow their instincts blindly, the states of European culture seek also to further their own interest, but it is a considered interest" that aligns on the "firm principles and rules" on which international community must be founded. ${ }^{23}$

One could multiply the examples of how notions of civilisation and nature are invoked to justify Europe's domination over other parts of the world. ${ }^{24}$ The pivotal role notions of nature and culture played in colonialism is so well established by now that we hardly need to rehearse the argument. We bring it up to illustrate that the imaginary of Europe presents two very different constitutional images. Depending on perspective, Europe appears as an anarchic state of nature, from which law will remain forever absent, or as a polity of peoples, in which right-ordering happens almost naturally. The latter image we find in the perhaps most influential manual of international law of the late eighteenth and nineteenth century, Georg Friedrich de Martens's Droit de Gens Moderne de l'Europe, first published in 1789 with numerous subsequent reprints. In spite of the growing discord between its states, we should, de Martens tells us, look upon Europe "as a whole that is separate from the rest of the universe, not only in terms of geography but as a specific assembly of states that, without having entered into actual society, has its own laws, its own mores, and its own customs and which can, in some respects, be seen as a people that has not yet given itself a constitution."25

We have chosen the quote because it calls to mind the description of constitutional pluralism by Neil Walker from which this section departed. On both approaches, the juxtaposition of the international and the constitutional aims at bringing the normative constraints of constitutionalism to bear on relations in which states were formerly thought to be subject to no, or only very few, constraints. And they do so in ways that are strikingly similar. The primacy of sovereignty means that the process of constitutionalisation proceeds without an identifiable mover. Movement is impelled by cultural inclination, which does its work in the context of the incessant, small-scale collisions that occur as states come up against each other in the pursuit of their selfinterest. It is this movement borne by a thousand insignificant events, which reflect conflict as much as they do community, that Walker describes in saying that post-polity constitutionalism will come about in "an 'agonistic' process of negotiation between alternative visions on the basis of consent and mutual respects."26

\footnotetext{
${ }^{23}$ Carl Bergbohm, Staatsverträge und Gesetze als Quellen des Völkerrechts (Tartu: C. Mattiesen, 1876), pp. 2-3 (my translation), cf. p. 110.

${ }^{24}$ On this point, see Amnon Lev, "The transformation of international law in the 19th century" in Alexander Orakhelashvili (ed.), Research Handbook on the Theory and History of International Law (Cheltenham: Edward Elgar, 2011), pp. 130-133.

${ }^{25}$ Georg Friedrich de Martens, Précis du Droit des Gens Moderne de l'Europe (Paris: Guillaumin et Cie, 1838 (1796)), I, p. 84 .

${ }^{26}$ Neil Walker, “The Idea of Constitutional Pluralism,” pp. 354, 359.
} 
Walker's confidence that the agonistic form interaction takes will not act as a solvent of consent and mutual respect trades on one of the key elements of the imaginary that nourished reflection on the state system, viz. a belief that antagonism, and conflict, opens up conduits for a culture of liberty to work itself out by surmounting its inherent contradictions. This idea, of which Hegel's lectures on world history are perhaps the paradigmatic example, survived the demise of the European state system. It is alive in the anguished account of Europe's political history that Benedetto Croce would produce in 1932 as storms were gathering over the continent, ${ }^{27}$ and it irrigates Walker's theory of constitutional pluralism.

We draw attention to the continuity not to take anything away from Walker's work, on the contrary. The point is to show how completely constitutional pluralism realises his ambition of "extending" the discourse of state-bound constitutionalism. Working from an intuition (pluralism), and using a grammar (polyvalence) that has no place in state-bound constitutionalism, he nevertheless produces a theory that is continuous with it. If its legal structures are different, it perpetuates the same discrete movement of liberty through history. Because Walker's theory does, in many respects, represent a break with the past, it also reveals something about the nature of the conduits through which ways of thinking law are transmitted across time. More specifically, it shows just how much may be riding on the use of specific metaphors, which, like the often-used image of a billiards table where objects collide within a closed space (and in the context of cultured society), take on an ideological function by naturalising certain interactional patterns and casting certain outcomes as all but inevitable.

The demonstration holds another implication that is essential for our purposes. It points to a limit of theory, a limit to what we can explain from theory. As the terms of Walker's constitutional pluralism are so similar to those that structure nineteenth century reflection on the state system, we cannot, simply by looking at them, explain why he is so confident that international relations between the states of Europe can be made to develop in constitutional ways, which is precisely what the publicists of the state system despaired of. It is clear that the answer must have something to do with sovereignty, which is the stumbling block for nineteenth century publicists. This is where we have to look beyond theory, or rather, we have to look differently at theory. To understand how ideas are made to do work that they previously could not, we have to determine how constitutional pluralism is situated, and how it situates itself, in history.

\footnotetext{
${ }^{27}$ Benedetto Croce, Storia d'Europa nel secolo decimonono (Milan: Adelphi Edizioni S.p.a., 1991 (1932), pp. 15-20, 433-434. On the function that this myth served in public law reflection on Europe, see Amnon Lev, "Federalism and the Ends of Europe" in Amnon Lev (ed.), The Federal Idea: Public Law between Governance and Political Life (Oxford: Hart Publishing, 2017), pp. 193-194.
} 


\section{The Unconscious and History}

We are attempting to grasp something intangible, a belief in how the world can, and should, be ordered. Often, it is only in retrospect, when belief is lost, that we can assess its strength and determine the specific functions it performed in making sense of the world. On this proviso, we shall try to get a reading on constitutional pluralism by working backwards from the changes that Walker makes to his theory in his 2016 intervention.

As will be remembered, Walker's concern in 2002 with how constitutional pluralism performed as a theory was such that it blanked out other considerations, including the question of practice. In 2016, the inattention to practice gives way to a much more fine-grained, and much less harmonious, account of the circumstances under which constitutional pluralism rose to prominence. Assessing its relevance, we are now told, requires more than finding the right level of theoretical enquiry; it requires taking into consideration "the appropriateness or otherwise of the theory and practice of [constitutional pluralism] to changing historical circumstances." 28 Underlying this change in perspective is a realisation that the questions to which constitutionalism proffers an answer do not interpellate us with the same strength at all times; their urgency is a function of history. In the early period of EU integration, the message of constitutional pluralism would have been of "limited political resonance" only. What made it resonate were post-Maastricht institutional developments that expanded the compass of integration, which in turn gave rise to anxieties at the level of national judicatures that "there was more at stake in deciding and declaring the authoritative foundations of the European polity, and that these foundations had become precariously balanced." 29

The irruption of history into theory goes hand in hand with a changing conception of the nexus of law and politics. It is striking that, in Walker's 2016 intervention, law occupies much the same place as it did fourteen years earlier. Politics, on the other hand, does not. Walker is keen to stress the continuity of his work, but the bind constitutionalism has on the political has clearly grown precarious. In 2002, he could allay the fear that law, for having no purchase on the political imagination, was incapable of generating "a new ethics of belonging" simply by noting that constitutional law is indispensable to the workings of any political imagination. ${ }^{30}$ That constitutional pluralism is a form of constitutional discourse warranted that it has (sufficient) purchase on political imagination to ensure that political life and constitutionalism would continue to align with and underpin each other. Fourteen years on, Walker has lost his faith in the power of constitutional theory to transcribe politics. No longer can law encompass all of politics. Walker stresses that constitutional pluralism must reach "beneath the legal topsoil to deeper political roots"; it should be considered "as much a matter of political theory as of legal theory." 31

\footnotetext{
${ }^{28}$ Neil Walker, “Constitutional Pluralism Revisited,” European Law Journal, 22/3, 2016, p. 337.

${ }^{29}$ Neil Walker, “Constitutional Pluralism Revisited,” pp. 347-348.

${ }^{30}$ Neil Walker, "The Idea of Constitutional Pluralism," pp. 326-327.

${ }^{31}$ Neil Walker, "Constitutional Pluralism Revisited," p. 335.
} 
Politics has been cut a-drift from law. The most telling indication of the disconnect is the paradox of initiative that Walker now identifies as one of the primary obstacles to making a supranational Europe work; the fact that the contemplation of a project of collective self-determination requires a form of consensus to engage in deliberations, and to respect the outcome. ${ }^{32}$ This paradox is not peculiar to the EU. It conditioned another project of institution building, namely that of the state. Hobbes too had to find ways of establishing a sense of community between agents who had no previous ties and everything to fear from one another. But Hobbes could paint the original position as a dystopia by comparison with which the commonwealth was infinitely preferable, even if it afforded only a simulacrum of political life, and even if the liberty that made life political was, for most, the liberty of being preyed on by those stronger than themselves. That strategy is not available to Walker. For him, the alternative to the European project is not a dystopia; it is a form of political life, to which the EU must simply show itself superior.

In making a case for constitutional pluralism, Walker trades on a belief that the member states of the European Union will, as they strive to realise their particular, self-interested ends, will remain mindful that at no point could they become so dominant as to exclude the irresolution on which the process of aggregative determination depends. This minimalist conception of political agency or political rationality, which we are wont to associate with Machiavelli but which goes back to Aristotle, ${ }^{33}$ is at the heart of the first iteration of constitutional pluralism. It warrants that a series of non-coordinated acts will converge around something like a common good, which explains the confidence with which Walker can assert that law's Other, the result of the "agonistic" process, will always be a form of politics. By coupling law always with politics in a process where agents can pursue their particular ends, establishing a common position between the member states of the EU becomes an exercise in political liberty that, without enlisting an identifiable mover, moves them towards their common, destinal end.

Against this backdrop, it is not hard to understand why Walker is so worried by the phenomenon of structural drift that he associates with the austerity measures imposed in the wake of the 2008 financial crisis. More than the specific nature of the measures, what worries him is that power has become unevenly distributed amongst member states - he speaks of the rise of "executive federalism" -, a sign that the process of aggregative determination is not governed by political rationality, or that political rationality is not strong enough to neutralise the non-political forces that are at work. Structural drift may only manifest itself at the surface, but it implicates the very springs of constitutional pluralism. Constitutional theory proceeds on a belief that law is preceded, and informed, by an always prior commitment to the constitutional enterprise. Absent this belief, we cannot narrate the development of the EU as a story of constitutionalism, over and above the

\footnotetext{
${ }^{32}$ Neil Walker, "Constitutional Pluralism Revisited," p. 350.

${ }^{33}$ The central passage is the tenth chapter of the third book of Aristotle's Politics. See the analysis in Amnon Lev, Filosofi og Politisk Toenkning hos Aristoteles (Copenhagen: Museum Tusculanum, 2008), pp. 109-125.
} 
story of how the competition between opposing interests and forces played out, which is much closer to a story of the market. ${ }^{34}$ This, by the way, would also make sense of why the references to the antagonistic nature of the process of integration disappear in the 2016 article, to be replaced by an emphasis on accommodation.

These are, in short, the changes that Walker makes to his theory, changes that reflect a significant scaling back of the ambitions of constitutional pluralism. The question is how we should understand the arc he follows over the fourteen-year period we have been concerned with; whether we can find a way, as I believe we must, to read this arc as tracking more than changes in how an author conceives of previous work. It is at this point that we shall relate constitutional theory to history, in the hope of showing that the best way to understand the shift is by placing it in the context of a transition between historical conjunctures. But before we can get to the nexus of theory and history, we need, first, to get clear about what it means for theory to be in history, how we can see theory as determined by history. Once we have put these preliminary questions of methodology behind us, we turn our attention to Walker's intervention to get a picture of what changes between them. Only on the basis of that determination can we show how constitutional pluralism reflects and entrenches a historically specific intuition of social life.

As for methodology, what we are looking for is a way to connect theory and history. Here, we look to the notion of the political unconscious that Fredric Jameson has developed as a means to analyse the linkages between literary texts and history. In a series of readings of classic and not-so-classic texts, he shows that, by correlating moments in the intrigue to material social contradictions, the text can be rewritten in terms of an antagonistic dialogue of class voices. ${ }^{35} \mathrm{We}$ are not suggesting that this methodology could be adopted wholesale in constitutional theory. The textual objects that Jameson studies work, and can be invested, in ways that cannot be replicated at the level constitutional theory operates on. Most importantly, in a literary text, we can give voice, within one narrative setting, to different positions in a social hierarchy, and to social formations belonging to different historical conjunctures, something constitutionalism, always tendentially univocal, does not allow for. This is why we shall have to rely on cross-textual comparisons to bring out the tension between layers of constitutional theory that refer to different temporal strata.

What we can take from Jameson's work is the insight that History operates as an absent cause in how a text configures, and invests, the social reality it is about. Moving closer to the methodological issues that concern us here, this means that the work of identifying how an author presses into service the relevant

\footnotetext{
${ }^{34}$ Michael A. Wilkinson makes a similar point in his cogently argued analysis of the impact of the Outright Monetary Transactions on the EU's constitutional equilibrium (see Michael A. Wilkinson, "Constitutional pluralism: chronicle of a death foretold?" (2017) 23 (3-4) European Law Journal 229-230.

${ }^{35}$ Fredric Jameson, The Political Unconscious (Abingdon: Routledge, 2002 (1981)), pp. 70, 168-169. Jameson insists that, ultimately, the meaning of a cultural form or artefact is determined by its link to a determinate mode of production (pp. 62, 78-80). At the same time, the thrust of his theory of the political unconscious is to distend the nexus between the means and forms of production and the determination of meanings, which opens up a space for analysing the work that certain abstract forms - forms of law - are doing in the determination of meaning.
} 
imaginary has to be supplemented by an analysis of what the socially available meanings are, and how they cluster round existing structures of authority (that may themselves be in a state of flux).

Seen in this light, the arc Walker follows from his first to his second intervention on constitutional pluralism is not only a story about the rise of executive federalism; it is also a story about how the constituent spheres of society - the political, the constitutional, and the economic - shift in relation to each other. We would therefore want to correlate the rise of executive federalism, an intra-legal determination, with the emergence, in the second iteration of Walker's theory, of the theme of economic rationality in the form of austerity regimes. The text invites the correlation, but in order to determine what is at stake here, we have to ask a question that might, at first glance, seem tangential but which holds the key to the problem that concerns us here. We have to ask why the theme of economic rationality did not feature in Walker's 2002 intervention on constitutional pluralism. Merely pointing to the events that austerity purports to respond to is not a sufficient explanation. Walker's concern is not with the austerity measures as such but with what they vehicle, viz. a rationality of close-minded self-interest that acts as a solvent of commitment to the constitutional enterprise. Surely, to the extent that we identify this form of rationality with economic rationality, it would always have been operative in an order that developed around the free movement of goods, capital, services, and labour. The question thus remains why economic rationality was not seen to constitute a threat to the constitutional enterprise in 2002.

Intuitively, we sense that this question implicates the very structure of constitutional pluralism; the level of threat must be a function of the equilibrium between law and politics on which constitutional pluralism rests. The loss of faith that constitutional theory can transcribe politics is the backdrop against which economic rationality appears. What we see in the transition between Walker's interventions is not simply a passage from constitutionalism to economics, but a more complex reconfiguration of the space of theory that involves the rise of economic rationality in EU governance and the appearance of a different kind of politics, one no longer coded by law but by the market. This is a movement, we might say, from a quasi-jusnaturalism where economic rationality is absent, and politics, overlaid by law, is only implicitly present to a full-blown triangulation of law, politics, and economic rationality.

Tension between law, politics, and economic rationality is not a recent phenomenon. It conditions the birth of the state and constitutes a matrix of its development. There is, in other words, a history of which the events in Walker's texts, if we can call them that, form part. What is novel about these events is that the triangulation of law, politics, and economic rationality plays out without reference to sovereignty, which, in the theory of the modern state, served to overawe the forces of market society. It will be objected that Walker retains the concept of sovereignty. But his late sovereignty is conceived in a way that strips it of the power to inspire awe, and to over-awe. From Hobbes to Hegel, sovereign power established its supremacy, and the supremacy of law over individual interest, by its exorbitant nature. It is the absence of a common measure between the power of the Leviathan and that of the individual's power that enables the former to impose its 
domination on the latter, and, in so doing, end the state of nature. The prospect of a resurgence of violence in the form of war justified the subordination of market society by calling to mind the ephemeral nature of all worldly possessions which the gods of war would claim as their due. ${ }^{36}$ At instinct level, constitutional theory continues to move in the shadow of this foundational myth, as reflected in the persistent critique of constitutional pluralism that the irresolution of judicial supremacy invites a resurgence of violent conflict, if not outright civil war. ${ }^{37}$

Late sovereignty is not capable of such feats. Walker tells us that boundaries between different polities will remain deeply contested in a multi-layered polity such as the EU, but in contrast to the territorial state, contest over jurisdictional boundaries will not involve an opposition of sovereign wills always likely to escalate into the clash of arms. ${ }^{38}$ As if to impress upon us that late sovereignty, this avatar of the mighty Leviathan, has been well and truly domesticated, Walker undercuts the myth of the creation of sovereignty as the foundational event of the polity; the assertion of sovereignty will often present itself as a "big-bang single moment," but this should not lead us into error. Such claims are "never more than provisional," and remain "remorselessly dependent on an ongoing dialectic of law and politics in which the earlier claim in either political or legal register will inevitably be conditioned by and represented, refined and perhaps significantly reshaped in the other register." 39

In 2003, law is capable of standing its ground against economic rationality in the fight for the soul of politics, and it does so without having to rely on the myth of an ex nihilo creation of the polity. From the vantage point of Walker's theory, we cannot account for how it maintains law's supremacy, in the process excluding from view the entire economic sphere. It is here that we leave behind Walker's theory to turn our attention to the historical conjuncture within which it moves, in the hope of finding an explanation of how it

${ }^{36}$ GW.F. Hegel, On the Scientific Ways of Treating Natural Law in Laurence Dickey and H.B. Nisbet (eds.), G.W.F. Hegel, Political Writings (Cambridge: Cambridge University Press, 1999 (1802)), pp. 140-141. Hobbes, to be fair, is more matter of fact in his approach. The threat of sliding back into the state of nature, which Hobbes sees realised first and foremost in interstate conflict, entails that the sovereign retains the ultimate right to property. Prior to the institution of a sovereign power, there is no distinction between mine and thine (Thomas Hobbes, Leviathan (Indianapolis: Hackett Publishing, 1994), I, xv, 3, p. 89, cf. xiii, 12, p. 79). At the level of political myth, the forces that the Leviathan keeps at bay are forces of interpersonal violence, but that violence moves in semantic proximity to the market. Hobbes knew that commercial transactions were shot through with domination, just as he knew that the sovereign had good reason to fear the rising class whose fortunes were tied to market society, i.e. the "merchants, whose profession is their private gain," who had sided with the King's enemies in the English Civil War (Thomas Hobbes, Behemoth or The Long Parliament (London: Simpkin, Marshall, and Co., 1889), p. 126.

${ }^{37}$ See, for example, Gareth Davies, "Constitutional Disagreement in Europe and the Search for Pluralism" in Matej Avbelj and Jan Komárek (eds.), Constitutional Pluralism in the European Union and Beyond (Oxford: Hart Publishing, 2012), p. 271; Martin Loughlin, "Constitutional pluralism: An oxymoron?," p. 19; Diarmuid Rossa Phelan, Revolt or Revolution: The Constitutional Boundaries of the European Community (Dublin: Round Hall Sweet \& Maxwell, 1997), p. 409. See also Joseph H.H. Weiler, "Does Europe Need a Constitution? Demos, Telos and the German Maastricht Decision," European Law Journal 1/3, 1995, p. 223.

${ }^{38}$ Neil Walker, "Late Sovereignty in the European Union," pp. 23, 25 with note 60.

${ }^{39}$ Neil Walker, "Late Sovereignty in the European Union," p. 20. 
managed to do the work of state theory - maintaining law's supremacy - without having at its disposal the most important conceptual resource of state theory, viz. sovereignty. The analysis of Walker's interventions has yielded a negative but useful result. By identifying what his theory could not do on its own terms, it traces the outline of where theory intersects with history.

This way of speaking should not mislead us into thinking that there is an immediate mapping of theory onto history, as if action could take over from theory as one runner can take over from another in a relay. Theory and history are not wholly soluble in one another; these are truths that no-one would think to question. It remains that in this case, mapping is unequivocal. The occlusion of the economic sphere and the in-operation of sovereignty pick out a determinate, historically specific, format of historical experience: on the one hand, the stakes have been raised to the point where it cannot be left to superior force to decide the outcome of conflict, and, on the other, political life has been redefined in a minimalist way so as to not appear in its difference from the freedom to pursue ones self-interest. This is the experience of an existential crisis threatening not only the individual state and its way of life, but the world to which it belongs.

The Cold War is exemplary of this experience. It reduced political life to survival in a context where the threat of mutually assured destruction made the idea of sovereignty, and of equilibrium between always antagonistic sovereign states, seem hopelessly outdated as governance mechanisms. ${ }^{40}$ The threat of impending destruction warranted the political nature of a European construction that was always first and foremost about the market. As it had done in Hobbes' theory of commonwealth some three centuries earlier, the supposition of an imminent existential threat meant that the building of order, any order, was already a political act, even if the life that awaited within the commonwealth did not deliver on our expectations of what a political life should look like. ${ }^{41}$

Beyond the Cold War, the experience of existential threat reaches back to the catastrophes of last century. The indetermination of sovereignty claims and the belief in the capacity of law to transcribe politics that Walker fashions into his theory of constitutional pluralism reflect the formative experiences of an order that claims its birthright from the slaughter of untold millions, and grew to maturity under the threat of total annihilation. In saying that History functions as an absent cause of Walker's theory, we are close to stating a trivial fact inasmuch as the theory's historical conjuncture reveals itself to be co-extensive with the history of

\footnotetext{
${ }^{40}$ A parallel argumentative strategy is deployed in developing global justice theory, a little more than a decade earlier. It bears saying that as Thomas Pogge, the most influential of global justice theorists, tries to find an institutional form to match his global justice theory, he looks to the European Union (see Amnon Lev, "To Every Thing There Is A Season: Theory, History, and Global Justice," Constellations).

${ }^{41}$ On the absence of a substantive conception of political life in Hobbes' theory of commonwealth, and the strategies he employs to remedy that absence, see Amnon Lev, Sovereignty and Liberty: A Study in the Foundations of Power (Abingdon: Routledge, 2014), pp. 77-80, 87-91.
} 
its object. It is perhaps not the least significant indication of the extent of the challenge to which Walker's theory rises that, in articulating a constitutional theory that is faithful to the lessons learned from the horrors of last century, he is using the language of the world that these horrors destroyed.

\section{Conclusion}

We have situated Walker's theory of constitutional pluralism in history, more precisely, in two histories between which it creates an unstable intersection: on the one hand, the history of constitutional theory and, on the other, the tormented political history of the twentieth century. If this entails a vindication of constitutional pluralism, albeit in terms not translatable into law, the deep embedding of the theory in the history of the European Union also raises questions about how we should understand the inflection it undergoes in Walker's 2016 intervention. How should we understand the disenchantment that comes through there, and what does it tell us about the European project it purports to describe?

As we have seen, Walker's sense of disenchantment is tied to the institution of austerity measures. Looking back on the last two decades, this choice may surprise some; as if nothing had happened between the end of the Cold War and the economic crisis that set in with the collapse of the Lehman Brothers bank in 2008. However, on the interpretation we have suggested, it is not hard to see why economic rationality would pose a greater threat to the constitutional cohesion of the European Union than jihadist terrorism and the refugee crisis of 2104 and 2015. Both can be accommodated within, indeed reinforce, the minimalist conception of survival politics where Europe is seen to be under constant threat. By discontinuing policies of redistribution, austerity measures, on the contrary, directly affect the way survival politics are felt by the people whose lives it governs. Austerity measures strike at the material comfort that the states of Europe were able to secure to their citizens, a comfort that is compatible with life in a survival mode. In this sense, we can see the 2016 intervention as the moment when one of the premier theorists of EU constitutionalism realises that the European project lacks the existential and social underpinnings that alone would make it a political endeavour.

Walker does not see that the root of evil runs deeper than the austerity measures; that it emanates from the conception of political life that is at the heart of European integration. His blindness is, in a part, a function of the way he understands the genealogy of sovereign power. The belief that the Other of late sovereignty is Westphalian sovereignty situates him in a historical arc in which the fundamental hiatus between the nineteenth and the twentieth century in how state power is conceived of does not appear. Thus, he does not see that the dis-entanglement of polity and constitutional discourse is not a political movement but premised rather on the demise of what made social life political. If polyvalence can serve as the criterion of integrability of institutional phenomena into constitutional discourse, it is not because the political plays out beyond the 
polity, but because the polity is no longer a site of political life, but the site of a survival politics that is no less real in an affluent society. ${ }^{42}$

One might want to elaborate this analysis into a critique of the project of European integration. The temptation to do so is undeniable, and we may be wrong to resist it. However, our concerns here have been methodological. We hope to have shown that unpacking the ways in which ideas and political intuition underpin and sustain one another in a specific theory of EU constitutionalism requires us to adopt a twopronged method of analysis in which we consider both the imaginary and the unconscious, the dimension of ideas and the dimension of history. Much more work will have to be done before we have a clear sense of how ideas have informed, and continue to inform, the project of ever-closer union. What we can say is that constitutional pluralism is particularly instructive in its fearless exploration of the ideas and historical forces that determine the capacity of law to order social life in ways that we recognise as political. In this sense, the doubts Walker shall come to hold about constitutional pluralism have implications that go beyond this particular undertaking of theory. Constitutional pluralism could reach the political roots of social life in a conjuncture where the release of certain pressures, and the unreflected persistence of others, allowed for the linking of past and present through the same imaginary. This conjuncture allowed for the alignment of an equilibrium principle that was predicated on the domination of market forces through sovereign power on the one hand and, on the other, a pluralism of irresolution in which sovereignty is seen as an emergent feature of forces about which constitutionalism could only assume that they were political. Ultimately, constitutional theory could not contain the tension between these forms of governance, and the commitments they carry. Time will tell whether the European Union can.

\footnotetext{
${ }^{42}$ For a lucid analysis of the political condition of the EU, see Michael A. Wilkinson, "Beyond the Post-Sovereign State?: The Past, Present, and Future of Constitutional Pluralism," Cambridge Yearbook of European Legal Studies (2019), especially pp. 9-11. The notion of survival politics can be glossed by reference to the idea of negative integration developed by Fritz W. Scharpf in his analysis of European integration (see Fritz W. Scharpf, "The asymmetry of European integration, or why the EU cannot be a 'social market economy'". Socio-Economic Review 8 (2010), pp. 221-224, 236238). As integration serves to dis-embed individual agency from the collective structures to which it was formerly tied, the centre of gravity of the new collective dimension that arises out of integration will remain tied to basic political goods.
} 


\section{Author(s):}

Title: The Imaginary and the Unconscious: Situating Constitutional Pluralism

iCourts Working Paper, No. 198, 2020

Publication date: 14/July/2020

URL: http://jura.ku.dk/icourts/working-papers/

(C) Author

iCourts Working Paper Series

ISSN: 2246-4891

Amnon Lev is Associate Professor in the Faculty of Law, University of Copenhagen E-mail: Amnon.Lev@jur.ku.dk

The iCourts Online Working Paper Series publishes pre-print manuscripts on international courts, their role in a globalising legal order, and their impact on politics and society and takes an explicit interdisciplinary perspective.

Papers are available at http://jura.ku.dk/icourts/

iCourts

- The Danish National Research Foundation's Centre of Excellence for International Courts The Faculty of Law University of Copenhagen Karen Blixens Plads 16 2300 Copenhagen $\mathrm{S}$ E-mail: icourts@jur.ku.dk Tel. +4535322626 